\title{
Analysis of Mathematical Problem Solving Abilites base on the Polya's Step Approach
}

\author{
$1^{\text {st }}$ Sahidi ${ }^{1}, 2^{\text {nd }}$ Syamsulrizal ${ }^{2}$ \\ \{dyon448@gmail.com ${ }^{1}$,syamsulrizal05@gmail.com² \}
}

Universitas Pendidikan Muhammadiyah Sorong, West Papua, Indonesia

\begin{abstract}
This research aims to describe the ability of students to solve mathematical problems using polya steps. The approach used in this study is a qualitative approach with research subjects in class VIII students of MTs Muhammadiyah Aimas Kab. Sorong. The research subjects are three students who have been selected based on their problem solving abilities which are categorized as one student with high ability, one student with medium ability and one student with low ability. Data obtained through interviews and three problem solving of geometry. The validity test used was the validity of the questions from the three questions each showed $0.817 ; 0.813$ and 0.677 this means that the three items are feasible to use, while for the reliability test shows 0.784 it shows that the problem solving ability test is included in the high category. The results of research that have been done show that students who are highly capable can understand the problem, able to make the planning stage, able to solve the problem with the right steps, and able to check answers. Students who are capable are able to understand the problem, able to plan, able to solve the problem, but are unable to check the answers again. Then for low-ability students who have not been able to understand the problem, have not been able to plan, are still unable to solve the problem and are unable to check again.
\end{abstract}

Keywords: Problem Solving Ability, Polya Steps, Quadrangle Questions.

\section{Introduction}

Problems in mathematics as a problem that students themselves are able to solve without using routine methods or algorithms (Ruseffendi 2006). The low problem solving ability of students, one of which is caused by learning that does not involve students so that students' activities are less optimal in learning (Ruseffendi, 2001; Sumarmo, 2005). If students are trained to solve problems, students will be able to gather various relevant information, analyze information and realize how necessary to re-examine the results that have been obtained (Herman, 2001).

Empirical evidence shows that there are still many students who experience difficulties in learning geometry, starting from the elementary level to the tertiary level. Various studies show that learning achievement is geometry. Based on research conducted by Sunardi (2001), it was found that many students were wrong in solving problems about parallel lines in junior high school students and there were still many students who stated that rhombus was not a parallelogram. Burger and Shaughnessy (1986) that students are often wrong in identifying images in learning geometry, and the difficulty in proving a theorem on geometry. Likewise, the results of the 2000/2001 Program for International Student Assessment (PISA) survey show that students are weak in geometry, especially in understanding space and form. 
Other research related to students' low problem solving towards learning geometry is also shown by (Lawson \& Chinnappan, 2000; Carlson \& Bloom, 2005;) showing that success in solving performance problems depends very much on the ability of the problem solver to pick up more knowledge, enable the link between schema knowledge and related information, and to coordinate them at the same time. Further research on problem solving in the study of gometry problem solving students is very influential on gender and has a different level of reasoning ability, so that different evaluations are carried out on the assessment of student geometry as a function of the van hiele level (Knight, 2006; Halat, 2008) .

Other studies have shown that many students have difficulty learning geometry and show poor performance in mathematics classes (Yetkin, 2003; Halat, 2007). This results in students being reluctant to learn geometry and ultimately the goal of learning geometry to develop problem-solving abilities cannot be achieved (Suwaji, 2008; Lembertus, 2010; Adolpuhus, 2011). This results in students being reluctant to learn geometry and ultimately the goal of learning geometry to develop problem solving skills cannot be achieved (Suherman, 2003).

NCTM (2000) recommends that new ideas, strategies, and research findings be utilized in teaching to help students overcome their difficulties in learning mathematics. In addition, knowledge of theoretical principles gives teachers an opportunity to develop practices that are more likely to succeed (Senk \& Thompson 2003).

Mathematical problem solving as a process of interpreting mathematical situations, which usually involves several repetitive cycles of expressing, testing, and revising mathematical interpretations-and sorting, integrating, modifying, revising or refining mathematical groups of concepts from various topics inside and outside mathematics (Lesh \& Zawojewski, 2007). Problem solving plays an important role in the curriculum for several reasons: 1) to build new mathematical knowledge; 2) to solve problems that arise in mathematics and in other contexts; 3 ) to implement and adapt various problem solving strategies; and 4) to monitor and reflect on the mathematical problem solving process (NCTM, 2000).

Mathematical problem solving is an activity of developing mathematical power towards students in solving story problems, solving non-routine problems, applying mathematics in daily life by using knowledge and the ability to solve them (Ruseffendi, 2001; Sumarmo, 2005; Susanto, 2012). Problem solving is a basic ability that must be mastered by students. Even reflected in the concept of competency-based curriculum. The demand for problem solving ability is explicitly emphasized in the curriculum, that is, as a basic competency that must be developed and integrated into a number of suitable material (Ruseffendi, 2001).

A mathematical problem solving is an abstract and complicated process and involves human thought and business reasoning looking for a way out of a difficulty, achieving a goal that is not immediately attainable (Usman, 2007). Mathematical learning emphasizes the existence of symbols generated through a process of generalization by making mathematical statements in various conditions (Lerch, 2004). While the aspect that must always be considered in mathematics learning is the way students think when they solve problems (Saad, 2004; Wahyudin, 2010; Memnun, et al, 2012).

Ruseffendi (2001) also suggests several reasons for the type of problem solving given to students, namely: 1) can lead to curiosity and motivation, foster creative nature; 2) in addition to having knowledge and skills, an ability to read and make a correct statement is required; 3 ) can lead to answers that are original, new, unique, and diverse, and can add new knowledge; 4) can improve the application of the knowledge it has acquired; 5) invites students to have a problem solving procedure, be able to make analysis and synthesis, and are required to make an evaluation of the results of the solution. 
Geometric thinking is a form of mathematical thinking, geometric thinking is quite difficult in understanding concepts. This is clearly a form of mathematical thinking in one particular content domain. It would be simpler to consider what students are expected to do in geometry and according to the model understand their thinking (NCTM, 2000).

Many factors cause the low geometrical ability of students in various levels of education, including teaching factors or learning techniques used by teachers. Usiskin (1982) explains that the quality of learning is one of the factors that has the greatest influence on student achievement in mathematics. Another weakness is weak learners in analyzing the problem monitor the completion process and evaluating the results (In'am, 2016).

Applications of mathematical problem solving require creative thinking and systematic processes and awareness in solving (In'am, 2015). Apart from creative thinking and systematic processes of course the process of resolution cannot be separated from the theory put forward by Polya's theory, which explains that in the actual mathematical problem solving someone has gone through 4 stages, namely: understanding the problem, determining the strategy, implementing the strategy, and reflect again (Polya, 1973). The theory that supports Polya's steps is Ausubel's theory, which suggests that receiving and discovering are the first steps in learning. The second step is trying to remember or master what is learned so that it can then be used (Jaeng, 2006).

The results of research conducted by Dewiyani (2008) show that Polya's steps can make students more skilled in solving mathematical problems. Based on the results of his research it was concluded that learning by using the Polya model problem solving approach can improve students' abilities in solving rectangular story problems and accustom students to think alternative, logical and responsible for solving problems.

The problem that will be given to this research is in the form of a story about a rectangle related to daily life. The story is a matter of being expressed in the form of a story taken from daily observations related to mathematical concepts. Provision of math questions in the form of stories provides experience for students to be able to solve mathematical problems and illustrate the relationship of these problems with their daily lives. This is in accordance with the opinion of Utomo (2005) that the problem in the form of a story in mathematics is difficult to solve, this happens partly because of the lack of students' ability to convert verbal sentences into mathematical models and the lack of ability to interpret mathematical solutions into real problems.

Polya's steps in solving problems have also been used by Nur Afriyanti (2013). The results of his research concluded that learning by using a problem solving approach according to Polya's steps in the model of problem based instruction on solving in Class VII SMP Negeri 7 Palu can improve students' ability to solve rectangular story problems and make students more directed in solving problems in form of story problems relating to daily life.

Based on the description above, the purpose of this study is to describe the application of Polya's steps in solving students' mathematical problems in the subject of rectangular language in Class VIII of MTs Muhammadiyah Aimas Kab. Sorong.

\section{Methods}

\section{Research Approach}

This research uses a descriptive qualitative approach. Qualitative approach is an approach aimed at describing and analyzing phenomena, events, social activities, attitudes, beliefs, 
perceptions, thoughts of people individually or in groups (Sugiyono, 2008). In addition, with a qualitative approach researchers can deal directly with respondents in analyzing students' problem solving abilities (Meleong, 2010). This type of research used in this study is a case study, namely the type of research carried out intensively, in detail and in depth on a particular organism, institution or object. The aim is to know firsthand the ability of students in solving problems the ability to solve problems on the subject matter of geometry quadrilateral with polya steps.

\section{Participant}

The subjects of the study were students of class VIII at MTs Muhammadiyah Aimas Kab. Sorong, amounting to 19 people. The method of taking research subjects by means of purposive sampling based on the objectives to be achieved is to know the ability of students' problem solving in terms of polya steps. Determination of the subject is determined based on the ability of students in answering questions. Based on the results of tests that have been carried out students are grouped into three groups, namely high, medium and low abilities. After selecting 3 research subjects, then each subject will be asked to work on problem solving problems that have been prepared by the researcher. Data collection was carried out by means of interviews and the results of the work of research subjects. Data obtained by recording all activities of students. The results of the interview were transcribed and coded to state the initials of the research subjects namely S3 for high-ability subjects, S2 for medium-capable subjects and S1 for low-ability subjects. The coding of problem 1 (M1), problem 2 (M2) and problem 3 (M3) and analyzed based on polya steps.

\section{Data Collection}

Data collection methods used to obtain research data through tests, interviews and documentaries. The test method is used to get data about the problem solving abilities of class VIII students in solving geometry problems. The test question used is a matter of description. Interviews are used to obtain data directly about the types of mistakes made by students in solving problems on problem solving tests and why the errors occur. The document is used to obtain data in the form of a list of names of class VIII students as a research class.

In this study the test results were analyzed by using SPSS version 21.0 for windows. Based on the results of calculations about the validity of each item after being trialled, each r-count $=$ 0.817 is obtained with a high interpretation; 0.813 with high interpretation and 0.677 with moderate interpretation. From the calculation results obtained reliability questions $r-11=0.784$, so that from the acquisition the test items can be used for research.

\section{Data Analysis}

Data analysis techniques used are data reduction, data presentation, data verification. Data reduction leads to the process of selecting, focusing, simplifying, abstracting, and transforming raw data written in the field notes. Presentation of data is done by displaying data sets that have been organized and categorized to allow conclusions to be drawn. The data presented in the form of student work, interview data, and analysis results in the form of errors of each research subject which is the data of findings.

\section{Result}

Presentation of the results of the study was carried out in sequence from high category students (S3), moderate category students (S2) and low category students (S1). The data is described based on the polya steps which include understanding the problem, planning the 
problem solving, implementing the problem solving plan and re-examining the results of the work on solving the problem. The ability to solve problems in terms of each step of solving the problem that has been given. Furthermore, the data obtained will be analyzed based on the classification of Subjects and the ability of students to solve problems in given rectangular problems.

After selecting 3 research subjects, then each subject will be asked to work on problem solving problems that have been prepared by the researcher. Data collection is done by interview and the results of the subject's work. Data obtained by recording all activities of students. Interview results were transcribed and coded using S3 for high-ability subjects, S2 for mediumcapable subjects, and S1 for low-ability subjects and followed by problem 1 (M1), problem 2 (M2) and problem 3 (M3). Here the researcher will analyze some of the work of students to see the ability to solve the problem of flat wake based on polya steps.

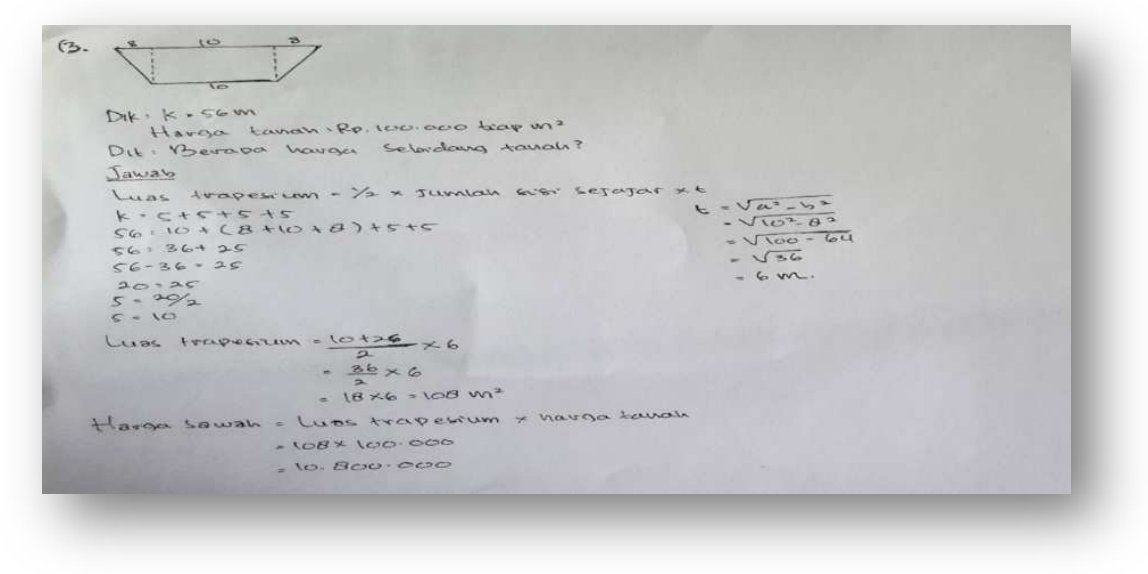

Fig.1. Student Work Results Expose the results of the work of the subject S3 in solving M3

\section{Understand the plan (Preparation)}

At this stage, S3 is able to explain what is known and what is asked precisely. So that the exposure of S3 is able to understand the problem.

Interview Transcript

Q: In problem number 3, a trapezoid-shaped parcel of land with a circumference of $28 \mathrm{~m}$ and two sides parallel to the length of $6 \mathrm{~m}$ and $12 \mathrm{~m}$. If the price of land is 100,000 per m, what is the price of the whole land? What is known and what is asked about the problem?

S3: trapezoid-shaped plot of land, with the price of each $m$ of paddy at a price of 100,000, around the $56 \mathrm{~m}$ of paddy field. If what is asked is what is the price of a piece of rice field?

$Q$ : What is the formula for trapezoidal area?

S3: half times the number of parallel sides multiplied by height sir ...?

$Q$ : If it is known that the price of each land is 100,000, how do you do?

S3: Yes, looking for trapezoidal area

Based on the interview transcript above, S3 also shows that the subject is able to answer the researcher's questions correctly by stating what is known and what is asked appropriately. So that $\mathrm{S} 3$ can be said to be able to understand the problem. 


\section{Devise a plan (Thinking a Time)}

At the stage of making a plan, it appears that the work of S3 is able to make a problem solving plan that is seen from writing the trapezoid formula. From this explanation S3 was able to make a settlement plan.

Interview Transcript:

Q: okay. After you determine the area of the trapezoid, what steps will you take?

S3: Looking for the height of the trapezoid first sir.

Q: How do you determine the height of the trapezoid?

S3: yes ,, by looking for the hypotenuse

Q: What steps do you take to determine the hypotenuse?

S3: You know the trapezoid around $56 \mathrm{~m}$, right sis. While the circumference formula is the number of sides there are two oblique sides so stay around it minus the number of parallel sides sir

Based on the results of the interview above it seems that it is able to answer the researcher's questions quite precisely. So based on the results of the interview the S3 can be said to be able to make plans.

\section{Carry Out The Plan (Insight)}

At this stage, what $\mathrm{S} 3$ does is apply from the plans made, so that $\mathrm{S} 3$ is able to find the final results of the problems that are given properly and correctly. From the presentation of the results of solving the problem, the $\mathrm{S} 3$ can be said to be able to carry out the settlement plan. Interview Transcript:

Q: After you get the high value of the trapezoid, what do you do next?

S3: Yes, look for the area of the trapezoid sir.

Q: How do you look for the area of the Trapezoid?

S3: have to do enter into the formula sis the number of lengths of parallel sides divided by 2 times the height

Q: After that, what steps do you take?

S3: Look for the price of the land, sir Area x price of each land. Found the price of a plot of land.

Based on the results of the interview above it appears that $\mathrm{S} 3$ is able to answer the questions posed by researchers properly and accurately. Therefore $\mathrm{S} 3$ is able to carry out the settlement plan.

\section{Look Back (Veryfication)}

At this stage, to check whether the answer is true or false S3 multiplies many trees by the distance between trees. as seen in the results of the interviews that have been conducted then S3 is said to be able to check the answers again.

Interview transcript

Q: Can you double check that your answer is right or wrong?

S3: Oh yeah, sir God willing, you can. Don't you get 100,000 prices per m, right, sir?

$Q:$ Yes, then what will you do?

S3: Yes, I did a test with the price of a plot of land divided by area. So 10.800,000 divided by $108=100,000$ right, sir.

Based on questions on $\mathrm{S} 3$ that can answer the researcher's questions appropriately. So here $\mathrm{S} 3$ can be agreed to answer again.

Based on the results of the examination given and the results of the interview S3 is able to understand problems and be able to plan and associate what is asked with what is known 
appropriately and well and be able to answer the problems given correctly and correctly for M3 and able to check the answers again.

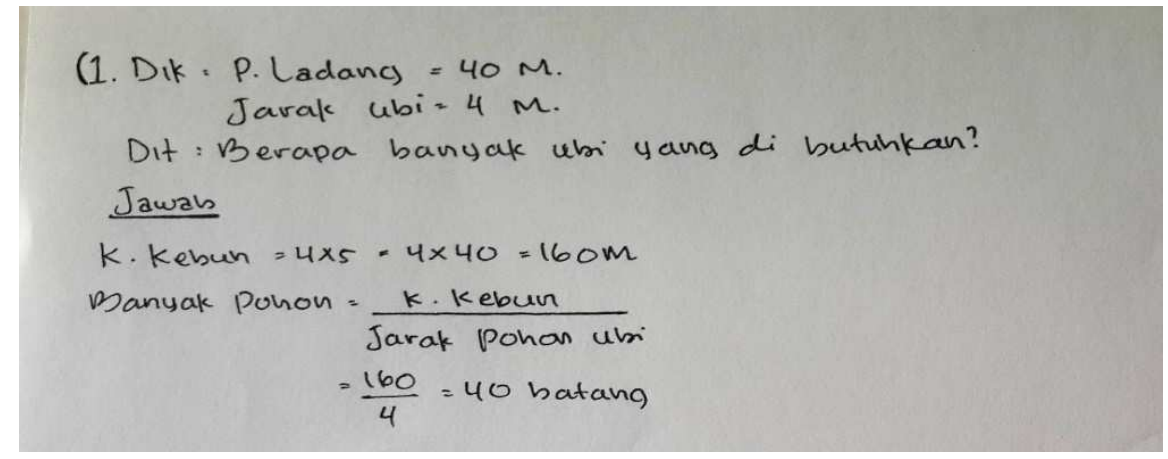

Fig.2. Exposes the work of the subject S2 in solving M1

\section{Understand the Problem (Preparation)}

At this stage, $\mathrm{S} 2$ is able to describe what is known and what is asked precisely. So, from the exposure of the $\mathrm{S} 2$ is able to understand the problem.

nterview Transcript

Q: Before you answer the questions you give what you did the first time?

S2: I will read the matter then I determine what is known and what is asked

Q: What is known and what is asked about the question can you describe it?

S2: The size of the field, the same distance between the corn trees

$Q:$ What is the size of the garden and the distance between the trees?

S2: $20 \mathrm{~m} \times 15 \mathrm{~m}$ and $7 \mathrm{~m}$

Based on the results of the interview above, $\mathrm{S} 2$ is able to understand the problems given

\section{Devise a Plan (Thinking Time)}

At the stage of making a plan, it can be seen that the work of S2 is able to create a problemsolving plan that is to determine the circumference of a rectangular field. After that, S2 determines the number of sweet potato trees with a square circumference divided by the distance between trees. From the explanation, S2 is able to make a settlement plan.

Interview Transcript:

Q: What steps do you take to determine how many corn trees are needed?

S2: Looking around the garden

$Q$ : How do you look around the garden?

$S 2: 2 p+2 l$

Based on the interview transcript above, S3's answers are correct and correct, so S3 can be said to be able to make plans.

\section{Carry Out The Plan (Insight)}

At this stage, what S2 does is calculate the circumference of the field, then calculate how many sweet potatoes are needed, ie the quotient of the perimeter with the distance and the correct answer. Then S2 can be said to be able to carry out the completion plan.

Interview Transcript: 
Q: On this question typed the size of the garden $20 \mathrm{mx} 15 \mathrm{~m}$ so how much is the circumference of the garden and the trunk of a corn tree needed?

S2: Yes, just enter it into the formula, $2 \times 35=70$ and for the area around the garden, the result is divided from 70 pieces to 7

Based on the interview results above it appears that the S2 is able to answer questions raised by researchers.

\section{Look Back (Veryfication)}

At this stage, S2 to check whether the answer is true or false S2 divides the number of tiles by two rectangular areas. Seen from the results of his work that the results are very precise. That means S2 is able to check again.

Interview transcript:

Q: What did you do to check that your answer was right or wrong?

S2: Yes ... more carefully

Q: Ok. how do you look closely?

S2: I counted again sir

Q: Yes ,, In counting again, but how do you count it so that the answer you get is correct?

S2: Hehehe ,, m'f sir, I don't know, I never check my answers

Based on the interview transcript above, it appears that S2 is not able to check the answers again. This is due to the fact that S2 never rechecks the answers in solving problems given by the teacher so that S2 does not understand how to check the right or wrong answers. So it can be said that $\mathrm{S} 2$ is not able to check again.

Based on the results of the test given and the results of the interview the S2 is able to understand the problem and is able to plan and associate what is asked with what is known appropriately and well and be able to fight to solve the problems given appropriately and correctly for M2 and yet the S2 is unable to check back the answer.

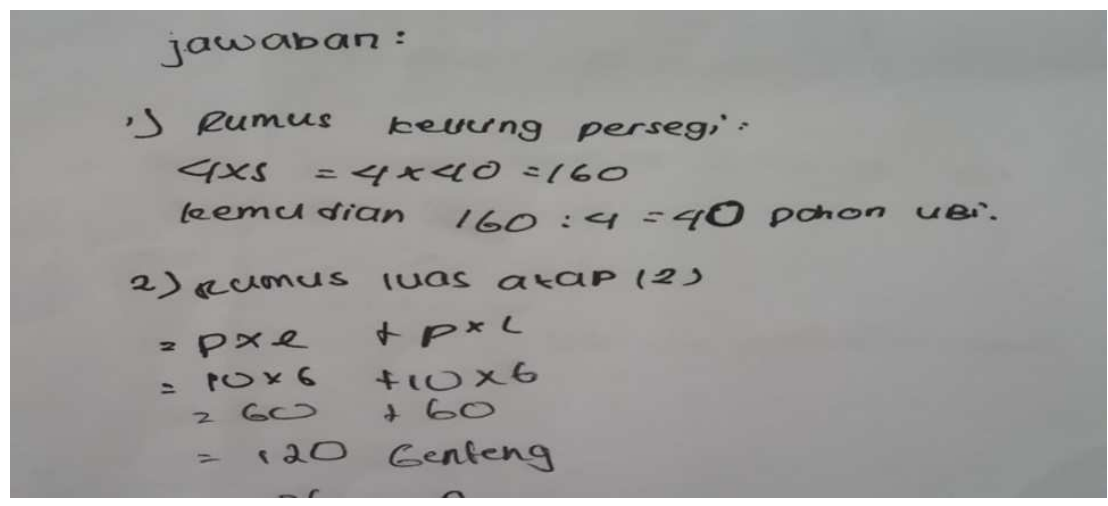

Fig.3. Expose the results of the work of Subject S1 in solving M1 and M2

\section{Understand the Problem (Preparation)}

In the stage of understanding the problem, $\mathrm{S} 1$ is able to write down what is known and what is asked. Then it can be concluded that $\mathrm{S} 1$ has not been able to understand the problem.

Interview Transcript:

Q: Can you read number 1 again?

S1: Mr. Andi has a square field, with a side length of $40 \mathrm{~m}$ 
Around the field will be planted with sweet potatoes. The distance of cassava is $4 \mathrm{~m}$. Help

Mr. Andi to determine how many sweet potatoes are needed?

$Q$ : Now from your question, do you read anything that is known and what is asked?

S1: ...........He is silent .... while understanding ...

S1: Mr. Andi has a square field, with a side length of $40 \mathrm{~m}$

$Q$ : What else is known about that problem?

S1: Distance of cassava tree $4 \mathrm{~m}$

Q: What do you ask about that?

S1: determine how many sweet potatoes are needed?

Q: Don't reread the problem. Try to understand again what was asked?

S1: How many sweet potatoes do you need, Andi?

Q: Why didn't you write it?

Based on the interview transcript above, it appears that S1 when asked by researchers about what is known and what is asked S1 is still reading the questions. So S1 has not been able to understand the problem given.

\section{Device a Plan (Thinking Time)}

At the stage of making a plan, it can be seen the answers from S1 directly carry out the completion plan, so that $\mathrm{S} 1$ does not draw up the plan in advance. So it can be concluded that $\mathrm{S} 1$ cannot develop a plan in solving the given problem.

Interview Transcript:

Q: Ok. Now we go to the next step in making a plan. What do you do next to determine the answer to the problem you gave?

S1: I don't understand sis? I just immediately do it

$P$ : oh so you didn't make a plan first in completing the problem I gave?

S1: No, I'll just go straight to the formula

Based on the interview transcript above, it appears that S1 when asked by researchers about compiling a plan before carrying out a settlement and S1 has not been able to draw up a plan of completion. So S1 can be said to have not been able to draw up a plan in solving the problems given.

\section{Carry Out the plan ( Insight)}

At the stage of implementing the completion plan, it can be seen from the answers S1 incorrectly answered, this is because the $\mathrm{S} 1$ is unable to understand the problem and formulate a settlement plan, so the S1 does not answer correctly. So it can be concluded that S1 is not able to carry out the completion plan.

Interview Transcript:

Q: To solve the problem that you gave, what did you do?

S1: just enter it into the formula

Q1: What is the formula ,,?

S1:

Based on the interview transcript above, it appears that S1 when asked by researchers about solving the $\mathrm{S} 1$ problem is only silent and the possible result is from the bench next door. That means it can be said that $\mathrm{S} 1$ has not been able to complete the completion plan 


\section{Discussion}

Based on the results of the study, it was found that in understanding S3 and S2 problems, they were able to understand the problem very well. Seen from their answers from the results of carrying out tests and interview results that are able to understand the question of the story well, they know what is known and what is asked about the question. While $\mathrm{S} 1$ has not been able to understand the problem, this can be seen from the answers obtained. The most important step in solving problems is at the stage of preparing a plan. If the aspect of making a plan is wrong and wrong then it is likely that the settlement will also be wrong. According to Soedjadi at this stage students are emphasized to make mathematical models that are in accordance with the given problem. In this aspect it is the most important step. Because it will affect the next stage. If the aspect of making a plan is wrong then most likely the next step will also be wrong.

Carrying out the completion plan S3 and S2 are able to solve the problem given in accordance with the preparation strategies they have prepared and use the steps and the calculation process is also correct. This is in line with Karmilah (2010) who argues that in carrying out the plan as outlined in the second step, an examination is carried out at each step in the plan and completed in detail to ensure that each step is correct. However, S1 has not been able to plan and solve problems in accordance with the plans drawn up. That is why S1 to solve the geometry problems of students must require understanding and planning in advance. This is also in line with the results of research conducted by Devi (2012) that there are still many students who have not yet understood and compiled a settlement plan so that they are not able to go to the next stage, namely the completion stage, for that students must be taught using a polya approach that is oriented towards 4 stages namely understanding, compiling a plan, implementing a completion plan and checking again. It is also in line with Sudarman (2007) that making problems as the foundation of learning can accustom students to solving problems that are equipped with a thorough understanding and compilation of plans.

Based on the data obtained on the performance of students in solving mathematical problems in the rectangular story, most students are still unable to solve the problem, it is due to the lack of understanding of students towards the problems given. This is in line with Murdanu (2004) states that one of the difficulties in solving geometry problems is caused by their lack of understanding. This was also confirmed by Suherman (2003) who stated students were reluctant to learn geometry and in the end the purpose of learning geometry to develop problem-solving abilities could not be achieved.

At the stage of re-checking S3 is able to re-examine the results of completion and be able to convince himself that the results of his work are correct. According to Karmilah (2010) that at the stage of re-checking, criticizing the results, this is different from the S2. In the results of other studies there are still many students who have not been able to make a settlement plan and recheck the results of their answers and there are still many of them who have difficulty in doing geometrical problems in the form of stories. This is in line with research conducted by Halat (2007) that many students have difficulty learning geometry and show poor performance in mathematics classes. This results in students being reluctant to learn geometry and ultimately the goal of learning geometry to develop problem-solving abilities cannot be achieved (Suwaji, 2008; Lembertus, 2010; Adolpuhus, 2011). 


\section{Conclution}

Based on the results and discussions that have been carried out, it can be concluded the ability of mathematical problem solving ability of students of class VIII MTs Muhammadiyah Aimas Kab. Sorong about building space in terms of polya steps are a) students with a high level of ability (S3) in solving problems according to the stage Polya has been able to understand the problem, draw up a settlement plan, carry out a settlement plan, and be able to check again; b) Students with a moderate level of ability (S2) in solving problems based on the Polya stage. Students are able to understand the problem, formulate a plan, able to complete the plan but have not been able to double check the correctness of the answers, and c) Students with a low level of ability ( S1) seems unable to understand the problem, formulate a plan, able to solve the problem and unable to check back in solving the problem of getting up flat.

Difficulties experienced by S1 in the aspect of understanding the problem that students are not accustomed to doing rectangular story problems with polya problem solving steps, do not understand the concept, and students can not manage the work process properly; difficulty aspects of planning that students have not been able to make mathematical models and students' ability to understand problems low; the difficulty of carrying out aspects is wrong in making mathematical models; Difficulties of looking back aspects are students do not know how to look back properly, students can not manage the time to work properly, and students are lazy attitude to check answers.

Because of that, it is recommended for teachers to continue to pay attention to students in terms of solving a problem in order to pay attention to the four polya steps namely understanding the problem, formulating a plan, carrying out a plan and checking again.

\section{References}

[1] Adolphus, T. Problems of Teaching and Learning of Geometry in Secondary Schools in Rivers State Nigeria. International Journal of Emerging Sciences. 2011.

[2] Afrianti, N.R. Penerapan Langkah Polya Dalam Model Problem Based Instruction Untuk Meningkatkan Kemampuan Peserta didik Menyelesaikan Soal Cerita Persegi Panjang. Jurnal Elektronik Pendidikan Matematika Tadulako, 1 (1) . 2013.

[3] Blanco, L. J., Barona, E. G. \& Carrasco, A. C.. Cognition and affect in mathematics problem solving with prospective teachers. The Mathematics Enthusiast, 10 (1 \& 2), 335-364. 2013.

[4] Burger, W.F \& Shaugnessy, J.M. Characterizing the Van Hiele Levels of Development in Geometry. Journal of Reserch in Mathematic Education. 17 (1), 31-48. 1986.

[5] Carlson, MP, \& Bloom, I. Siklus sifat pemecahan masalah: Sebuah muncul multidimensi. 2005.

[6] Dewiyani. Mengajarkan Pemecahan Masalah dengan Menggunakan Langkah Polya. Jurnal Pendidikan (Online), 12 
Tersedia:http://isjd. pdii.lipi.go.id/admin/jurnal/ 122088796.pdf. 10 Agustus 2014. 2008.

[7] Halat. Reform-based curriculum \& acquisition of the levels. Eurasia Journal of Mathematics, Science and Technology Education. 3 (1), 41-49. 2007.

[8] Halat. Pre-Service Elementary School And Secondary Mathematics Teacher's Van Hiele Levels And Gender Differences. IUMPST.The Journal. 3 (1), 41-49. 2008.

[9] Hudoyo, H. Pengembangan Kurikulum dan Pembelajaran Matematika. Malang: Fakultas MIPA Universitas Negeri Malang. 2001.

[10] In'am, A. Euclidean Geometry's Problem Solving Based on Metacognitive in Aspect of Awareness. International Electronic Journal of Mathematics Education. 11 (4), 961-974. 2016.

[11] In'am, A. Menguak penyelesaian masalah matematika:analisis pendekatan metakognitif dan model Polya. Yogyakarta: Aditya Media. 2015.

[12] Jaeng, M. Belajar dan Pembelajaran Matematika. Palu: FKIP UNTAD. 2006.

[13] Karmilah. Pengembangan Kemampuan Komunikasi dan Pemecahan Masalah serta Disposisi Matematis Mahapeserta didik PGSD Melalui Pembelajaran Berbasis Masalah. Disertasi UPI. Bandung : Tidak diterbitkan. 2010.

[14] Knight, K.C.. An investigation into the change in the van hiele level of understanding geometry of pre-service elementary and secondary mathematics teachers. Unpublished Masters Thesis. University of Main. 2006.

[15] Lawson, MJ, \& Chinnappan, M. Pengetahuan keterhubungan di masalah geometri pemecahan. Journal Penelitian di Matematika Pendidikan, 31 (1), 26-43. 2000.

[16] Lembertus. Pengaruh Pembelajaran Berbasis Masalah Terhadapa Kemampuan Pemecahan Masalah, Komunikasi dan Resresntasi Peserta didik SMP. Disertasi FPMIPA UPI: tidak diterbitkan. 2011.

[17] Lesh, R., \& Zawojewski, JS. Pemecahan masalah dan pemodelan. Charlotte, NC: Era Informasi. 2007.

[18] Murdanu. Analisis kesulitan peserta didik SLTP dalam menyelesaikan persoalan geometri, Tesis PPS Universitas Negeri Surabaya. 2004.

[19] Meleong. (2010). Metodologi Penelitian Kualitatif. Bandung: Remaja Rosdakarya

[20] Memnun, D. S., Hart, L. C. \& Akkaya, R. A Research on the mathematics problem solving belief of mathematics, science and 
elementary pre service training in Turkey in term of Different Variables. International Journal of Humanities and Social Sciences, 2 (24). 2012.

[21] NCTM. Principle and Standards for School Mathematics. Reston, VA: NCTM. 2000.

[22] Polya G. How to Solve It. New Jersey :Princeton University Press 1973.

[23] Ruseffendi, E.T. Dasar-dasar Penelitian Pendidikandan Bidang NonEksakta Lainnya. Bandung: PT. Tarsito. 2005.

[24\} Ruseffendi, E.T. Pengantar Pembantu Guru Mengembangkan Kompetensinya dalam PengajaranMtaematika untuk Meningkatkan CBS. Bandung: PT. Tarsito. 2006.

[25] Saad, N. Perlakuan metakognitif peserta didik tingkatan empat aliran sains dalam penyelesaian masalah matematik tambahan. Kajian Jabatan Matematik, Fakulti Sains dan Teknologi Universiti Pendidikan Sultan Idris. 2004.

[26] Schoenfeld, AH. Pemecahan masalah matematika. Orlando, FL: Academic Press. 1985.

[27] Senk, S. L., \& Thompson, D. R. Middle school mathematics curriculum reform. In S. L. Senk \& D. R. Thompson (Eds.), Standards-based school mathematics curricula. What are they? What do students learn? (181-192). Lawrence Erlbaum Associates: NJ. 2003.

[28] Sri Mulyati. Geometri Euclide. Note Book Kerjasama JICA, Malang: UM Press. 2000.

[29] Sudarman. Problem Based Learning: Suatu Model Pembelajaran untuk Mengembangkan dan Meningkatkan Kemampuan Memecahkan Masalah. (Online), Vol. 22.

http://physicsmaster.orgfree.com/Artikel $\% 20 \% 26 \% 20 \mathrm{Jurnal} / \mathrm{Waw}$ asan\%20Pendidikan/P BL\%20Model.pdf. Diakses Tanggal 14 Februari 2013. 2007.

[30] Sugiyono. Metode Penelitian Pendidikan, Pendekatan Kuantitatif, Kualitatif dan R\&D. Bandung: Alfabeta. 2008.

[31] Suherman, E. Strategi Pembelaran Matematika Kontemporer. Bandung: JICA. 2003.

[32] Sumarmo, U. Dedy. E dan Rahmat. Suatu Alternatif Pengajaran Untuk Meningkatkan Pemecahan Masalah Matematika Pada Guru Dan Peserta didik SMA. Laporan Hasil Penelitian FPMIPA IKIP Bandung. 2005. 
[33] Susanto, H. A. Pemahaman Mahapeserta didik Field Independent dalam Pemecahan Masalah Pembuktian pada Konsep Guru. Aksioma Jurnal Pendidikan Matematika, 1 (1). 2012.

[34] Suwaji, U.T. Permasalah pembelajaran geometri Ruang SMP dan Alternatif Pemecahannya. P4TKM Yogyakarta: Depdiknas. 2008.

[35] Usiskin, Z. Van Hiele Levels and Achievement in Secondary School Geometry. (Final report of the Cognitive Development and Achievement in Secondary School Geometry Project.) Chicago: University of Chicago. 1982.

[36] Usman, S. Strategi Pemecahan Masalah dalam Penyelesaian Soal Cerita di Sekolah Dasar. LIPI. (Online), 2 (2). http://isjd.pdii.lipi.go.idadminjurnal2207341351.pdf. Diakses Tanggal 23 Desember 2012. 2007.

[37] Utomo, Y. Mengatasi Kesulitan Peserta didik Dalam Menyelesaikan Soal Cerita Sistem Persamaan Linear Dua Variabel Melalui Belajar Kelompok Di Kelas 2A SMP Al-khairat II Palu. Skripsi tidak diterbitkan. Palu: FKIP Universitas Tadulako. 2005.

[38] Wahyudin. Peranan problem solving dalam matematika, Bandung: FPMIPA UPI. 2010.

[39] Yetkin, E. Student difficulties in learning elementary mathematics. ERIC Clearinghouse for Science, Mathematics, and Environmental Education, DIGEST, EDO-SE-03-06. 2003. 